\title{
R Factor Transfer in Rhizobium leguminosarum
}

\author{
By J. E. BERINGER \\ Department of Genetics, John Innes Institute, Colney Lane, Norwich NOR 70 F
}

(Received I9 April I974)

\begin{abstract}
SUMMARY
$\mathbf{R}$ factors of the compatibility class $\mathbf{P}$ were transferred between strains of Escherichia coli $\mathrm{KI} 2$ and Rhizobium leguminosarum. These R factors were stable in $R$. leguminosarum and conferred similar levels of antibiotic resistance to those in the corresponding $\mathrm{R}^{+} E$. coli $\mathrm{KI} 2$ hosts, with the exception of carbenicillin resistance which was greatly reduced. Transfer between $R$. leguminosarum strains was by conjugation and was stimulated by conditions favouring spheroplast formation. $\mathrm{R}$ factor mediated recombination could not be demonstrated.
\end{abstract}

\section{INTRODUCTION}

Rhizobium leguminosarum is potentially a particularly suitable species for use in genetical studies of symbiotic nitrogen fixation as it is the partner of a legume, the pea (Pisum), that is itself well-known genetically. However, though there have been reports of transformation (Balassa, I963; Raina \& Modi, 1972), transduction (Kowalski, I97I ; Sik \& Orosz, I97I) and conjugation (Heumann, I968; Heumann, Pühler \& Wagner, I97I, 1973) in various species of Rhizobium, no suitable method of genetic analysis exists for $R$. leguminosarum.

The $\mathrm{R}$ factor transfer experiments described in this paper were initiated as a method for determining the ability of these bacteria to transfer DNA by conjugation and in the hope that $\mathrm{R}$ factor mediated recombination could be demonstrated. $\mathrm{R}$ factors belonging to the compatibility class $\mathrm{P}$ were chosen, as members of this class have been shown to be transferable between different genera of bacteria (Sykes \& Richmond, 1970; Roe, Jones \& Lowbury, I97I; Datta et al. 197I; Datta \& Hedges, 1972a; Olsen \& Shipley, 1973) and more specifically because transfer of such $\mathrm{R}$ factors was reported to occur from Escherichia coli to Rhizobium trifolii and $R$. meliloti (Datta et al. 197I ; Datta \& Hedges, I972a) and also between $R$. lupini strains (Pühler, Burkardt \& Heumann, 1972).

\section{METHODS}

Bacterial strains and plasmids are listed in Table $\mathrm{I}$.

Isolation of $R$. leguminosarum strains. Pea root nodules were cut from the root system, still attached to a small piece of root to eliminate damage, washed in water and then treated with sodium hypochlorite ( $12 \%, \mathrm{w} / \mathrm{v}$, available chlorine) for 3 to $10 \mathrm{~min}$, depending on their size. The nodules were then washed twice in sterile distilled water, broken open with a sterile needle and the contents streaked out on TY agar plates (defined below). After 5 to 7 days' incubation, Rhizobium-like colonies were subcultured to further TY plates for single colony isolation. Initial characterization of strains was by their ability to grow on a number of different complete and minimal media; the final characterization was by a nodulation test. 
Table I. Bacteria and plasmids

Bacteria

$\begin{array}{cc}\left.\begin{array}{r}\text { Rhizobium leguminosarum } \text { strains* } \\ 240 \\ 262 \\ 30 \mathrm{I}\end{array}\right\} & \text { Wild-types } \\ 4 \mathrm{I} & \\ \mathrm{I} 07 & \text { ade ura str-r } \\ \mathrm{I} 37 & \text { ilv } \\ \mathrm{I} 45 & \text { ilv his str-r } \\ \mathrm{I} 47 & \text { leu } \\ \mathrm{I} 96 & \text { leu } \\ 209 & \text { pur } \\ \text { Escherichia coli } \mathrm{KI} 2 & \text { strains } \\ \mathrm{J} 5-3 \text { nal-r } & \mathrm{F}^{-} \text {pro met nal-r } \\ & \\ \mathrm{RC} 24 & \mathrm{~F}^{-} \text {thr leu thi lac str-r } \\ \mathrm{J} 6-2 & \mathrm{~F}^{-} \text {pro trp his lac }\end{array}$

\section{Reference or source}

Isolated from pea root nodules

NTG mutagenesis of $30 \mathrm{I}$

NA mutagenesis of 240

NTG mutagenesis of 107

NA mutagenesis of $30 \mathrm{I}$

NA mutagenesis of 262

NA mutagenesis of 301

NA mutagenesis of $30 \mathrm{r}$

Clowes \& Hayes (1968)

Dr E. Meynell

Lawn \& Meynell (1970)

Dr E. Meynell

Clowes \& Hayes (1968)

Dr N. Datta

\begin{tabular}{|c|c|c|c|c|}
\hline $\mathbf{R}$ factors & $\begin{array}{c}\text { Resistance } \\
\text { markers } \dagger\end{array}$ & $\begin{array}{l}\text { Compatibility } \\
\text { group }\end{array}$ & Source & References \\
\hline $\begin{array}{l}\text { RP4 } \\
\text { R6886 } \\
\text { RK2 } \\
\text { R751 } \\
\text { R702 }\end{array}$ & $\begin{array}{l}\text { A,T,K } \\
\text { A,T,K } \\
\text { A,T,K } \\
\text { Tp } \\
\text { S,T,K,Su,Hg }\end{array}$ & $\begin{array}{l}\mathrm{P} \\
\mathrm{P} \\
\mathrm{P} \\
\mathrm{P} \\
\mathrm{P}\end{array}$ & $\begin{array}{l}\text { Dr N. Datta } \\
\text { Dr E. J. L. Lowbury } \\
\text { Dr L. Ingram } \\
\text { Dr N. Datta } \\
\text { Dr N. Datta }\end{array}$ & $\begin{array}{l}\text { Holloway \& Richmond (1973) } \\
\text { Holloway \& Richmond (1973) } \\
\text { Jobanputra \& Datta (1974) }\end{array}$ \\
\hline $\begin{array}{l}\text { R40a } \\
\text { R57b }\end{array}$ & $\begin{array}{l}\mathrm{K}, \mathrm{Su}, \mathrm{A} \\
\mathrm{Ge}, \mathrm{A}, \mathrm{C}, \mathrm{Su}\end{array}$ & $\begin{array}{l}\mathrm{C} \\
\mathrm{C}\end{array}$ & $\begin{array}{l}\text { Dr N. Datta } \\
\text { Dr N. Datta }\end{array}$ & Datta \& Hedges $(1972 b)$ \\
\hline R I44drd3 & $\mathbf{K}$ & I & Dr E. Meynell & Cooke, Meynell \& Lawn (I970) \\
\hline $\mathrm{R} I d r d \mathrm{I} 9$ & $\mathrm{~K}, \mathrm{C}, \mathrm{A}, \mathrm{S}, \mathrm{Su}$ & $\mathbf{F}$ & Dr E. Meynell & Cooke et al. (1970) \\
\hline
\end{tabular}

* The R. leguminosarum strains were tested for their symbiotic properties as described in Methods: $30 \mathrm{I}$, 240, 262, 196, 209 and 209(RP4) were infective and effective; I45 and I47 were infective and ineffective; 4 I was non-infective.

+ Symbols for resistance to: ampicillin (A), tetracycline (T), kanamycin/neomycin (K), streptomycin (S), sulphonamides $(\mathrm{Su})$, mercury $(\mathrm{Hg})$, gentamycin $(\mathrm{Ge})$, chloramphenicol $(\mathrm{C})$, trimethoprim $(\mathrm{Tp})$.

Media. All media were made with distilled water and, when required, were solidified with I. $5 \%$ Oxoid No. 3 agar. NB and NA were Oxoid nutrient broth and agar. MM was the minimal medium of Vogel \& Bonner (1956). TY contained, per litre, $5 \mathrm{~g}$ Difco BactoTryptone, $3 \mathrm{~g}$ Difco Bacto-yeast extract and $\mathrm{I} \cdot 3 \mathrm{~g} \mathrm{CaCl}_{2} \cdot 6 \mathrm{H}_{2} \mathrm{O}$. SY was the minimal medium of Sherwood (I970) modified by using sodium succinate at $\mathrm{I} \cdot 35 \mathrm{~g} / \mathrm{l}$ in place of mannitol; after autoclaving, biotin, thiamine hydrochloride and calcium pantothenate were added, each to a final concentration of I $\mathrm{mg} / \mathrm{l}$. VS was Vincent's (1970) yeast sucrose (phage) broth.

Antibiotics were used as freshly prepared solutions in distilled water and were added to media at the following final concentrations (mg/l). For E. coli: kanamycin sulphate, 25; trimethoprim, ro; carbenicillin, roo for selection of $\mathrm{R}$ factor transfer and 1000 to demonstrate high level resistance; tetracycline $\mathrm{HCl}$, Io. For $R$. leguminosarum: kanamycin sulphate, 25; trimethoprim, 50; carbenicillin, 50; streptomycin sulphate, 500; tetracycline $\mathrm{HCl}$, $\mathrm{I}$. The antibiotic resistance patterns of strains were tested by means of Oxoid Multodiscs and by growth on antibiotic-supplemented media. Trimethoprim lactate was a gift from 
J. S. Inman of The Wellcome Foundation Ltd, Berkhamsted, Hertfordshire. Other antibiotics were purchased as proprietary brands.

$R$ factor transfer. For $E$. coli, late log-phase nutrient broth cultures (about $5 \times 10^{8} / \mathrm{ml}$ ) were mixed in a donor-recipient ratio of about $\mathrm{I}: 5$ and added to an equal volume of fresh pre-warmed NB. Crosses were incubated without shaking at $37^{\circ} \mathrm{C}$ for I h, diluted in the buffer of Clowes \& Hayes (I968) and plated on selective media.

For $R$. leguminosarum, late log-phase cultures (about $5 \times 10^{9} / \mathrm{ml}$ ) were prepared by growing donors and recipients separately on TY slants at $28^{\circ} \mathrm{C}$ for $48 \mathrm{~h}$ and washing the bacteria off the slants with VS medium. Equal ( $\mathrm{I} \mathrm{ml}$ ) volumes of donors and recipients were added to $8 \mathrm{ml}$ VS and incubated with gentle shaking for $20 \mathrm{~h}$ unless otherwise indicated. Samples were diluted in distilled water and plated on selective minimal media. Frequencies of transfer were calculated per recipient.

In crosses between $E$. coli and $R$. leguminosarum and where more than one recipient was used, donors and recipients were cultured as above. Equal ( $\mathrm{I} \mathrm{ml}$ ) volumes of donor and recipient(s) were then added to VS medium to a final volume of $\mathrm{Io} \mathrm{ml}$ unless otherwise indicated. Mating was for $20 \mathrm{~h}$ at $28{ }^{\circ} \mathrm{C}$ with gentle shaking and samples were diluted in buffer before plating on selective minimal media. Frequencies of transfer were calculated per recipient.

Plate crosses were performed by replica plating plates carrying patches of up to six strains of $R$. leguminosarum on to plates spread with a dense suspension of bacteria of the $\mathrm{R}^{+}$ parent. The resulting plate crosses were incubated at $28{ }^{\circ} \mathrm{C}$ for $24 \mathrm{~h}$ and then replicated to suitable selective media. This procedure was based on that used with Streptomyces coelicolor by Sermonti \& Casciano (I963) and by Hopwood, Harold, Vivian \& Ferguson (1969).

$\mathrm{R}^{+}$transconjugants derived from all crosses were routinely tested for non-selected markers of either parent and for the acquisition of all $\mathrm{R}$ factor mediated resistances. Control platings of donors and recipients were made to determine the spontaneous mutation rate of markers selected in crosses. In $R$. leguminosarum spontaneous resistance to tetracycline was never observed and that to kanamycin was infrequent (about $10^{-9} /$ cell plated) and was readily lost. For crosses in liquid medium, viable counts of donors, recipients and $\mathrm{R}^{+}$ transconjugants were taken from the average of three plate counts at suitable dilutions on selective media.

Mutagenesis. Auxotrophic mutants of $R$. leguminosarum were induced by treatment with $N$-methyl- $N^{\prime}$-nitro- $N$-nitrosoguanidine (NTG) using the following procedure, based on that of Scherrer (I970). Log-phase cultures growing in VS (pH about 7.2) at $28^{\circ} \mathrm{C}$ were treated with $200 \mathrm{mg}$ NTG/l for $\mathrm{I} h$; the bacteria were washed twice in distilled water and then resuspended in VS and incubated for about $20 \mathrm{~h}$ to allow segregation and expression of mutations. Suitable dilutions were plated on TY and colonies growing on these plates were replicated to SY medium for the detection of auxotrophic mutants. SY medium was supplemented with sodium succinate to reduce the amount of exopolysaccharide which is produced by rhizobia growing on minimal media containing glucose or mannitol (Dudman, 1964). This greatly increased the number of individual colonies that could be handled per plate (200 to 300 as opposed to 10 to 20 ), because the final size of colonies on succinate medium was governed more by the volume of bacteria present than by the amount of exopolysaccharide that they could produce. Multiply-marked mutants were produced by repeated NTG treatment. Nitrous acid (NA) mutagenesis was as described by Kaudewitz (I959).

Spontaneous streptomycin-resistant mutants were obtained by plating about $10^{8}$ bacteria on TY supplemented with I $\mathrm{mg}$ streptomycin $/ \mathrm{ml}$. 
Table 2. $R$ factor transfer between $E$. coli and $R$. leguminosarum

Crosses were performed as described in Methods using a mixed E. coli-R. leguminosarum recipient culture in $40 \% \mathrm{NB}+60 \% \mathrm{VS}$ as the mating medium.

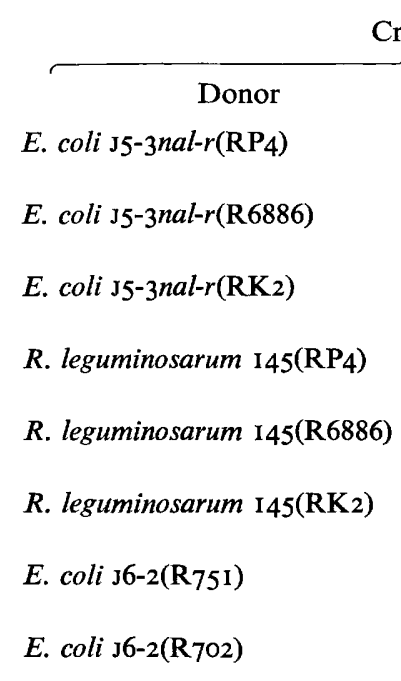

Cross

(2)

Recipients




\section{Table 3. Effect of $N B$ or glycine on $R$ factor transfer}

Crosses were performed as described in Methods except that NB or glycine were added to the mating medium at the concentration shown. Selection for $\mathbf{R}$ factor transfer was by kanamycin in suitably supplemented minimal media.

\begin{tabular}{|c|c|c|c|c|c|}
\hline \multirow[b]{2}{*}{ Cross } & \multicolumn{3}{|c|}{ Viable count per ml } & \multirow{2}{*}{$\begin{array}{l}\mathbf{R}^{+} \text {recipients } \\
\text { per recipient }\end{array}$} & \multirow{2}{*}{$\begin{array}{c}\mathrm{NB} \text { in } \\
\text { medium }(\%)\end{array}$} \\
\hline & $\mathrm{R}^{+}$donors & Recipients & $\mathrm{R}^{+}$recipients & & \\
\hline \multirow[t]{2}{*}{$4 \mathbf{I}\left(\mathrm{RP}_{4}\right) \times \mathbf{I} 45$} & $\begin{array}{l}4.9 \times 10^{7} \\
3.5 \times 10^{8} \\
2.9 \times 10^{8} \\
6.2 \times 10^{8} \\
8.1 \times 10^{7} \\
\sim 1 \times 10^{6} \\
\sim 6 \times 10^{5}\end{array}$ & $\begin{array}{l}1 \cdot 7 \times 10^{9} \\
3 \cdot 1 \times 10^{9} \\
2 \cdot 4 \times 10^{9} \\
1 \cdot 7 \times 10^{9} \\
1 \cdot 3 \times 10^{8} \\
\sim 3 \times 10^{6} \\
\sim 2 \times 10^{6}\end{array}$ & $\begin{array}{l}\sim 2 \times 10^{2} \\
1 \cdot 1 \times 10^{4} \\
1 \cdot 5 \times 10^{4} \\
4 \cdot 4 \times 10^{3} \\
8 \cdot 1 \times 10^{3} \\
1 \cdot 0 \times 10^{3} \\
<1 \times 10^{2}\end{array}$ & $\begin{array}{r}\sim \mathrm{I} \cdot 2 \times 10^{-7} \\
3.6 \times 10^{-6} \\
6 \cdot 3 \times 10^{-6} \\
2.6 \times 10^{-6} \\
6.2 \times 10^{-5} \\
\sim 3.3 \times 10^{-4} \\
<5 \times 10^{-5}\end{array}$ & $\begin{array}{l}0 \\
10 \\
20 \\
30 \\
40 \\
50^{*} \\
60^{*}\end{array}$ \\
\hline & & & & & $\begin{array}{l}\text { Added glycine } \\
(\mathrm{mg} / \mathrm{ml})\end{array}$ \\
\hline \multirow[t]{6}{*}{$I_{45}\left(R_{4}\right) \times 4 I$} & $1 \cdot 7 \times 10^{9}$ & $1 \cdot 1 \times 10^{9}$ & $2 \cdot 2 \times 10^{4}$ & $2 \cdot 0 \times 10^{-5}$ & 0 \\
\hline & $\mathrm{I} \cdot \mathrm{I} \times 10^{9}$ & $9.1 \times 10^{8}$ & $8.2 \times 10^{4}$ & $9 \cdot 0 \times 10^{-5}$ & $0 \cdot 19$ \\
\hline & $5.7 \times 10^{8}$ & $8.7 \times 10^{8}$ & $1 \cdot 0 \times 10^{5}$ & $\mathrm{I} \cdot \mathrm{I} \times 1 \mathrm{IO}^{-4}$ & $0 \cdot 37$ \\
\hline & $1 \cdot 5 \times 10^{8}$ & $3.7 \times 10^{8}$ & $2.5 \times 10^{5}$ & $6.8 \times 10^{-4}$ & 0.52 \\
\hline & $9 \cdot 3 \times 10^{6}$ & $5.4 \times 10^{7}$ & $6.6 \times 10^{4}$ & $1 \cdot 2 \times 10^{-3}$ & 0.74 \\
\hline & $6.7 \times 10^{6}$ & $2.0 \times 10^{7}$ & $2 \cdot 9 \times 10^{4}$ & $1.4 \times 10^{-3}$ & 0.94 \\
\hline
\end{tabular}

* Plate counts after growth in $50 \%$ or higher levels of NB were more variable than expected from errors in dilution and plating.

was regained. A similar effect was observed by Grinsted et al. (1972), who showed that $E$. coli strain W3IIO(RPI) produced about 50 times more $\beta$-lactamase than Proteus mirabilis strain Pr-I carrying the same R factor. Differences in the level of R-TEM mediated $\beta$-lactamase activity in $E$. coli and $P$. mirabilis have also been reported by Smith (1969) and Hesslewood \& Smith (1974). Though $\beta$-lactamase levels were not measured in $R$. leguminosarum these results would suggest that impaired phenotypic expression, rather than genetic alteration of the plasmids, was responsible for the level of resistance observed.

Transfer of $\mathrm{R}$ factors was tested in crosses between single donors and recipients and also with mixed $E$. coli-R. leguminosarum recipient cultures. Mixed recipients were used to give a direct comparison between the frequency of inter- and intra-generic transfer of the plasmids under the same mating conditions and also to be certain that $\mathrm{R}^{+}$donors were able to transfer the plasmids under these conditions. Using mixed recipients a number of crosses were performed to detect transfer of the $\mathrm{C}$ group $\mathrm{R}$ factors $\mathrm{R}_{40 a}$ and $\mathrm{R} 57 \mathrm{~b}$, the F-like $\mathrm{R}$ factor $\mathrm{R} I d r d \mathrm{I} 9$ and the I-like $\mathrm{R}$ factor R $\mathrm{I}_{4} 4 d r d_{3}$ from $E$. coli to $R$. leguminosarum. Transfer of $R_{40 a}$ and $R_{57} \mathrm{~b}$ was tested as it has been reported that R40a was transmissible from Pseudomonas aeruginosa to E. coli (Datta \& Hedges, 1972b); RIdrdI9 and RI44drd3 were tested as they transfer at high frequency between $E$. coli strains and have been used to mediate chromosomal transfer between members of the Enterobacteriaceae (Cooke \& Meynell, 1969; Dixon \& Postgate, 1971; Moody \& Hayes, 1972). None of these plasmids was transferred to $R$. leguminosarum at a detectable level ( $\mathrm{I}^{-9}$ or above), though transfer to the $E$. coli recipients in these crosses was always observed. 

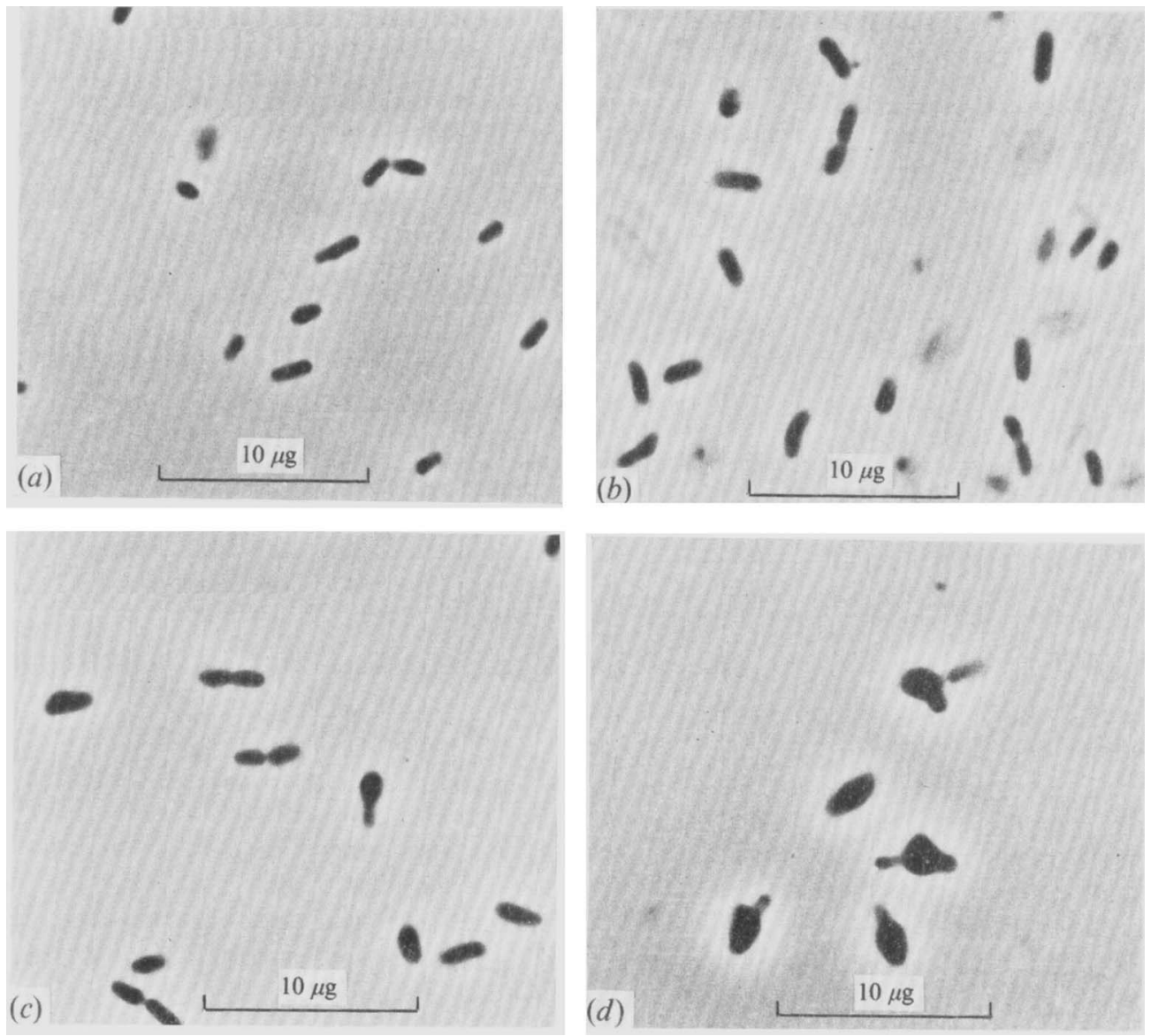

Fig. I. Effect of $(a) \circ,(b) 30,(c) 40$ and $(d) 50 \%$ of NB in VS medium on the morphology of $R$. leguminosarum strain 107 after $20 \mathrm{~h}$ incubation at $28^{\circ} \mathrm{C}$.

\section{Effects of medium composition on $R$ factor transfer}

Transfer of $\mathrm{RP}_{4}$ between $R$. leguminosarum strains in liquid medium (VS) crosses occurred less frequently than between $E$. coli or $P$. aeruginosa strains crossed in nutrient broth (NB). As rhizobia are inhibited by high levels of amino acids (Jordan \& Coulter, 1965; Skinner \& Roughley, 1969), mating could not be performed in NB; therefore crosses were made in liquid media containing different proportions of VS and NB to determine whether a rich medium was advantageous.

NB had two main effects on R factor transfer (Table 3). Low levels apparently enriched the medium and enabled the bacteria to reach a higher final density after $20 \mathrm{~h}$ incubation, and this also had the effect of increasing the yield of $\mathrm{R}^{+}$recipients. The frequency of transfer was also stimulated by increased levels of NB up to a point where the yield of donors and recipients was severely reduced. This point, about 40 to $50 \% \mathrm{NB}$, also corresponded to the point where swollen and distorted bacteria could first be observed (Fig. I).

Sherwood (1972) reported that the inhibition and morphological changes induced in rhizobia by high levels of yeast extract were mainly due to the glycine present. Therefore, crosses were performed in VS containing different amounts of glycine to test whether the effect of NB on $\mathrm{R}$ factor transfer in $R$. leguminosarum was due to the provision of essential 


\section{Table 4. Transfer of $\mathrm{RP}_{4}$ in plate crosses}

Plate crosses were performed as described in Methods, selecting for RP4 transfer with kanamycin and counter-selecting donors by their growth requirements.

Donor
4I(RP4)
IO7(RP4)
I45(RP4)
I47(RP4)

No. of isolates tested for recipient ability

63

52

70

65
No. of isolates

that received $\mathrm{RP}_{4}$

Table 5. Lack of effect of DNase on $R$ factor transfer

Crosses were performed as described in Methods, in $40 \% \mathrm{NB}+60 \%$ VS with and without DNase at $40 \mu \mathrm{g} / \mathrm{ml}$.

Viable count (per $\mathrm{ml}$ of culture)

\begin{tabular}{|c|c|c|c|c|c|c|}
\hline \multirow[b]{2}{*}{ Cross } & \multicolumn{3}{|c|}{ +DNase* } & \multicolumn{3}{|c|}{-DNase } \\
\hline & $\begin{array}{c}\mathrm{R}^{+} \\
\text {Donors }\end{array}$ & Recipients & $\underset{\text { recipients }}{\mathbf{R}^{+}}$ & $\begin{array}{c}\mathbf{R}^{+} \\
\text {donors }\end{array}$ & Recipients & $\underset{\text { recipients }}{\mathbf{R}^{+}}$ \\
\hline $\mathrm{I} 45(\mathrm{RP} 4) \times 4 \mathrm{I}$ & $2.6 \times 10^{9}$ & $1.6 \times 10^{9}$ & $1.9 \times 10^{4}$ & $7.1 \times 10^{8}$ & $1 \cdot 3 \times 10^{9}$ & $1.2 \times 10^{4}$ \\
\hline $4 \mathrm{I}\left(\mathrm{RP}_{4}\right) \times \mathrm{I} 45$ & $1 \cdot 2 \times 10^{9}$ & $3 \cdot I \times 10^{9}$ & $3.5 \times 10^{3}$ & $8.5 \times 10^{8}$ & $8.2 \times 10^{8}$ & $1 \cdot 6 \times 10^{3}$ \\
\hline
\end{tabular}

* DNase ( $\mathrm{I} \mathrm{ml}$ ) at $400 \mu \mathrm{g} / \mathrm{ml}$ in $0.2 \mathrm{M}-\mathrm{MgSO}_{4}$, was added to $9 \mathrm{ml}$ of mating medium.

metabolites required for conjugation or to the glycine it contained. Transfer was stimulated by the addition of glycine and the effect of glycine was similar to that with NB (Table 3 ). As with NB, the level which was responsible for a reduced yield of donors and recipients was found to be the one where morphological changes in the bacteria could be observed.

\section{Host range for $\mathrm{RP}_{4}$ transfer}

To determine whether $\mathrm{R}$ factors could be transferred to a wide range of $R$. leguminosarum strains, four different $\mathrm{R}^{+}$donors were crossed with a large number of distinct 'wild-type' isolates (Table 4). Of 52 isolates plate crossed with all four donors, only five were found that would not act as recipients of $\mathrm{RP}_{4}$ from any of the donors. No obvious differences, such as bacteriocin production or sensitivity, could be determined between these strains and those which acted as recipients. The data show a widespread ability of $R$. leguminosarum strains to act as recipients of $\mathrm{RP}_{4}$ in crosses of this type.

\section{Lack of effect of deoxyribonuclease on $R$ factor transfer between} $R$. leguminosarum strains

If transfer of $\mathrm{R}$ factors between $R$. leguminosarum strains were due to spontaneous transformation, the presence of deoxyribonuclease (DNase) in the mating medium would prevent, or at least lower, the frequency of transfer. Crosses were performed in the presence and absence of DNase (Koch Light, bovine pancreas) under conditions giving optimal levels of R factor transfer (Table 5). The data show that transfer was not inhibited by DNase.

\section{Stability of $R$ factors}

Stanisich \& Holloway (197I) reported that R6886 was unstable in Pseudomonas aeruginosa strain PAT and that the tetracycline and kanamycin/neomycin determinants of RI822 were 
lost on transfer of this R factor between P. aeruginosa strains. Grinsted et al. (1972) observed that this separation of antibiotic resistance markers could occur spontaneously with RPI in $P$. aeruginosa and Ingram et al. (1972) suggested that this might be a result of integration of the carbenicillin resistance determinant into the host chromosome. Furthermore, Olsen \& Shipley (1973) reported that RI822 was unstable in strains of Neisseria perflava, Rhodospirillum rubrum and Rhodopseudomonas spheroides.

Three $\mathrm{R}^{+} R$. leguminosarum strains were tested for the stability of the plasmids they carried by repeatedly subculturing on antibiotic-free TY agar and then plating for single colonies on antibiotic-free SY agar. These colonies were then replicated to plates of SY medium containing kanamycin, tetracycline or carbenicillin. I examined II 47 colonies of strain I45(RP4), I649 colonies of strain I45(R6886) and I620 colonies of strain I45(RK2), but detected no separation of resistance determinants or loss of $\mathrm{R}$ factors. No loss of $\mathrm{R}$ factor markers has been observed from any other R. leguminosarum strain in this laboratory.

\section{$R$ factor mediated recombination}

Chromosomal gene transfer mediated by $\mathrm{R}$ factors in members of the Enterobacteriaceae has been well documented (Cooke \& Meynell, I969; Dixon \& Postgate, I97I; Moody \& Hayes, 1972) and has also been demonstrated in P. aeruginosa using R factors of the compatibility class $\mathrm{P}$ (Stanisich \& Holloway, 197I). Crosses between $R$. leguminosarum strains were performed to look for recombinant formation associated with $\mathrm{R}$ factor transfer. These crosses were performed as described in Methods using $40 \% \mathrm{NB}+60 \% \mathrm{VS}$ as the mating medium; selection was for $\mathrm{R}$ factor transfer and recombinant formation for individual auxotrophic markers of both parents. In over 30 crosses of this type, involving transfer of $\mathrm{RP}_{4}, \mathrm{R} 6886, \mathrm{RK}_{2}$ and $\mathrm{R} 75 \mathrm{I}$ between suitable pairs of the $R$. leguminosarum strains described in Methods, no increased frequency of prototroph formation over the spontaneous mutation rate (usually less than $\mathrm{I}^{-8}$ ) was observed for any marker tested, though $\mathrm{R}$ factor transfer occurred at a frequency of $1 \mathrm{O}^{-3}$ to $1 \mathrm{I}^{-5}$.

\section{DISCUSSION}

These results show that $R$. leguminosarum, like many other Gram-negative bacteria (Datta et al. I971; Datta \& Hedges, I972a; Olsen \& Shipley, 1973), can act as a recipient or donor of $\mathbf{P}$ group $\mathrm{R}$ factors in mixed culture with other bacteria. The insensitivity of this transfer to deoxyribonuclease, the wide range of $R$. leguminosarum strains that are able to act as recipients of $\mathrm{R}$ factors, and the observation that transfer can occur both to and from E. coli, make conjugation the most likely mode of transfer. Therefore, as was originally anticipated, $\mathrm{R}$ factor transfer experiments have provided a method for demonstrating conjugation in $R$. leguminosarum.

An unusual feature of crosses involving $R$. leguminosarum strains was the effect of NB or glycine on the frequency of $\mathrm{R}$ factor transfer. These crosses indicated that, in the presence of high levels of amino acids or glycine in the mating medium, the bacteria were unable to grow and divide normally and, therefore, when samples from a cross were plated on selective media the number of donors and recipients recovered from the mating medium declined. Furthermore, the frequency of R factor transfer was stimulated by added glycine or NB up to the point where growth was severely affected. A reasonable interpretation of these results is that high levels of glycine (and possibly other amino acids present in NB) in the medium induce spheroplast formation and interfere with cell division. The formation of partial spheroplasts at low levels of NB could have a similar beneficial effect on mating 
properties to that observed with some bacteria as a result of mutation from the 'smooth' to the 'rough' phenotype (Jarolmen \& Kemp, I969; Heumann, 1968) as in both cases changes in the outer layers of the bacteria are involved. This interpretation is consistent with the following: high levels of glycine are known to induce spheroplast formation in bacteria (McQuillen, 1960; Strominger \& Birge, 1965); rhizobia are sensitive to high levels of glycine and yeast extract in media and these cause spheroplast formation (Jordan \& Coulter, 1965; Sherwood, 1972). Examination of mating mixtures containing different levels of NB or glycine in the light microscope showed that the optimum frequency of $\mathrm{R}$ factor transfer occurred at a level of NB or glycine that induced obvious morphological changes in the bacteria. Having observed this effect, future crosses were performed in a medium containing $40 \% \mathrm{NB}: 60 \% \mathrm{VS}$.

The inability to demonstrate transfer of chromosomal markers mediated by $\mathrm{R}$ factor transfer was not unexpected, in comparison with $\mathrm{R}$ factor mediated recombination in the Enterobacteriaceae (Pearce \& Meynell, I968; Cooke \& Meynell, 1969; Dixon \& Postgate, I97I). In these well-characterized systems the frequency of recombinant formation for most chromosomal markers is about $\mathrm{IO}^{5}$ times lower than that for transfer of the $\mathrm{R}$ factor. Therefore, de-repressed transfer mutants able to transfer at approximately $100 \%$ efficiency are needed to give reasonable numbers of recombinants. Transfer of $\mathrm{P}$ group $\mathrm{R}$ factors between $R$. leguminosarum strains was at approximately the same level as that of repressed $\mathrm{R}$ factors in the Enterobacteriaceae and it can therefore be assumed that chromosomal mobilization might well have been too infrequent to be observed. The recent report by Cole \& Elkan (1973) that Rhizobium japonicum carries extrachromosomal antibiotic resistance genes, and that these can be transferred by conjugation to Agrobacterium tumefaciens, suggests that future studies of conjugation in $R$. leguminosarum would benefit from a search for selftransmissible plasmids that might already be present in Rhizobium strains.

I am grateful to Professor D. A. Hopwood for his advice and assistance during the preparation of this paper, and to those who so readily provided me with bacterial cultures.

\section{REFERENCES}

Balassa, G. (1963). Genetic transformation of Rhizobium: A review of the work of R. Balassa. Bacteriological Reviews 27, 228-24I.

Cartwright, P. M. (1967). The effect of combined nitrogen on the growth and nodulation of excised roots of Phaseolus vulgaris. Annals of Botany N.S. 3I, 309-32 I.

Clowes, R. C. \& Hayes, W. (1968). Experiments in Microbial Genetics. Oxford and Edinburgh: Blackwell Scientific Publications.

Cole, M. A. \& ElKan, G. H. (I973). Transmissible resistance to penicillin G, neomycin, and chloramphenicol in Rhizobium japonicum. Antimicrobial Agents and Chemotherapy 4, 248-253.

CoOKe, M. \& MEYNELL, E. (1969). Chromosomal transfer mediated by de-repressed R factors in $\mathrm{F}^{-}$Escherichia coli KI2. Genetical Research 14, 79-87.

CoOke, M., MeYnell, E. \& LAWN, A. M. (I970). Mutant Hfr strains defective in transfer: restoration by F-like and I-like de-repressed R factors. Genetical Research 16, IOI-II 2.

DAtTA, N. \& HedGes, R. W. ( $1972 a$ ). Host ranges of R factors. Journal of General Microbiology 70, 453-460.

Datta, N. \& Hedges, R. W. (1972 b). R factors identified in Paris, some conferring gentamycin resistance, constitute a new compatibility group. Annales de l'Institut Pasteur 123, 849-852.

Datta, N., Hedges, R. W., Shaw, E. J., Sykes, R. B. \& Richmond, M. H. (I97I). Properties of an R factor from Pseudomonas aeruginosa. Journal of Bacteriology 108, 1244-I 249.

Dixon, R. A. \& Postgate, J. R. (I97I). Transfer of nitrogen-fixation genes by conjugation in Klebsiella pneumoniae. Nature, London 234, 47-48.

Dudman, W. F. (1964). Growth and extracellular polysaccharide production by Rhizobium meliloti in defined medium. Journal of Bacteriology 88, 640-645. 
Grinsted, J., Saunders, J. R., Ingram, L. C., Sykes, R. B. \& Richmond, M. H. (i972). Properties of an $\mathrm{R}$ factor which originated in Pseudomonas aeruginosa 1822. Journal of Bacteriology 110, 529-537.

Hesslewood, S. R. \& SMITH, J. T. (1974). Inhibition of R-factor-mediated beta-lactamase by Proteus mirabilis. Antonie van Leeuwenhoek (in the Press).

HeumanN, W. (1968). Conjugation in star-forming Rhizobium lupini. Molecular and General Genetics ro2, 132-144.

Heumann, W., Pühler, A. \& Wagner, E. (197I). The two transfer regions of the Rhizobium lupini conjugation. I. Fertility factor elimination and one way transfer. Molecular and General Genetics $\mathbf{1} 3$, 308-3I5.

Heumann, W., PüHler, A. \& Wagner, E. (1973). The two transfer regions of the Rhizobium lupini conjugation. II. Genetic characterization of the transferred chromosomal segments. Molecular and General Genetics 126, 267-274.

Holloway, B. W. \& Richmond, M. H. (1973). R factors used for genetic studies in strains of Pseudomonas aeruginosa and their origin. Genetical Research 21, I03-I05.

Hopwood, D. A., Harold, R. J., Vivian, A. \& Ferguson, H. M. (I969). A new kind of fertility variant in Streptomyces coelicolor. Genetics 62, 46I-477.

Ingram, L., Sykes, R. B., Grinsted, J., Saunders, J. R. \& Richmond, M. H. (1972). A transmissible resistance element from a strain of Pseudomonas aeruginosa containing no detectable extrachromosomal DNA. Journal of General Microbiology 72, 269-279.

JAROLMEN, H. \& KEMP, G. (1969). Association of increased recipient ability for R factors and reduced virulence among variants of Salmonella choleraesuis var. kunzendorf. Journal of Bacteriology 97, 962-963.

JobanpurRa, R. S. \& DATTA, N. (1974). Trimethoprim resistance factors in enterobacteria from clinical specimens. Journal of Medical Microbiology (in the Press).

Jordan, D. C. \& Coulter, W. M. (1965). On the cytology and synthetic capacities of natural and artificially produced bacteriods of Rhizobium leguminosarum. Canadian Journal of Microbiology 11, 709-720.

Kaudewitz, F. (1959). Production of bacterial mutants with nitrous acid. Nature, London 183, 1829-1830.

KowAlski, M. (I97I). Transduction in Rhizobium meliloti. Plant and Soil, Special Volume, pp. 63-66.

Lawn, A. M. \& Meynell, E. (1970). Serotypes of sex pili. Journal of Hygiene 68, 683-694.

MCQuillen, K. (1960). Bacterial protoplasts. In The Bacteria, vol. I, pp. 249-359. Edited by I. C. Gunsalus and R. Y. Stanier. New York: Academic Press.

Moody, E. E. M. \& HAYES, W. (1972). Chromosome transfer by autonomous transmissible plasmids: the role of the bacterial recombination ( $\mathrm{rec}$ ) system. Journal of Bacteriology III, 80-85.

Olsen, R. H. \& ShIPley, P. (1973). Host range and properties of the Pseudomonas aeruginosa R factor Ri 822. Journal of Bacteriology $113,772-780$.

Pearce, L. E. \& Meynell, E. (I968). Specific chromosomal affinity of a resistance factor. Journal of General Microbiology 50, I 59-172.

Pühler, A., Burkardt, H. J. \& Heumann, W. (1972). Genetic experiments with the Pseudomonas aeruginosa $\mathrm{R}$ factor RP4 in Rhizobium lupini. Journal of General Microbiology 73, xxvi.

RAINA, J. L. \& MoDI, V. V. (1972). Deoxyribonucleate binding and transformation in Rhizobium japonicum. Journal of Bacteriology Irr, 356-360.

RoE, E., Jones, R. J. \& Lowbury, E. J. L. (1971). Transfer of antibiotic resistance between Pseudomonas aeruginosa, Escherichia coli and other Gram-negative bacilli in burns. Lancet i, I49-152.

SCHERRER, A. (1970). Etude des propriétés symbiotiques de certains mutants auxotrophs de Rhizobium meliloti. Faculté des Sciences d'Orsay, D. E. A. d'Amélioration des Plantes, octobre I970.

Sermonti, G. \& Casciano, S. (1963). Sexual polarity in Streptomyces coelicolor. Journal of General Microbiology 33, 292-301.

Sherwood, M. T. (1970). Improved synthetic medium for the growth of Rhizobium. Journal of Applied Bacteriology 33, 708-713.

SHERWOOD, M. T. (1972). Inhibition of Rhizobium trifolii by yeast extracts or glycine is prevented by calcium. Journal of General Microbiology 7r, 35I-358.

Six, T. \& Orosz, L. (197I). Chemistry and genetics of Rhizobium meliloti phage 16-3. Plant and Soil, Special Volume, pp. 57-62.

Skinner, F. A. \& Roughley, R. J. (1969). Rothamsted Report Part I, pp. IOI-102.

SMiтh, J. T. (1969). R factor gene expression in Gram-negative bacteria. Journal of General Microbiology $\mathbf{5 5}$, I09-120.

Stanisich, V. A. \& Holloway, B. W. (I97I). Chromosome transfer in Pseudomonas aeruginosa mediated by $\mathrm{R}$ factors. Genetical Research $\mathbf{1 7}, 169-172$. 
Strominger, J. L. \& Birge, C. H. (1965). Nucleotide accumulation induced in Staphylococcus aureus by glycine. Journal of Bacteriology 89, I $124-1$ I 27.

SyKes, R. B. \& RICHMOND, M. H. (1970). Intergeneric transfer of a beta-lactamase gene between Ps. aeruginosa and E. coli. Nature, London 226, 952-954.

Vincent, J. M. (1970). In A Manual for the Practical Study of the Root-nodule Bacteria. I.B.P. Handbook no. 15. Oxford and Edinburgh: Blackwell Scientific Publications.

VOGEL, H. J. \& BONNER, D. M. (1956). Acetylornithinase of Escherichia coli: partial purification and some properties. Journal of Biological Chemistry 218, 97-106. 